\title{
Professor Judith Elizabeth Adams: Leading skeletal radiologist and expert in adult and paediatric bone densitometry
}

\author{
K. A. Ward $^{1} \cdot$ Z. Mughal ${ }^{2}$
}

Received: 14 October 2017 / Accepted: 18 October 2017 /Published online: 2 November 2017

(C) International Osteoporosis Foundation and National Osteoporosis Foundation 2017

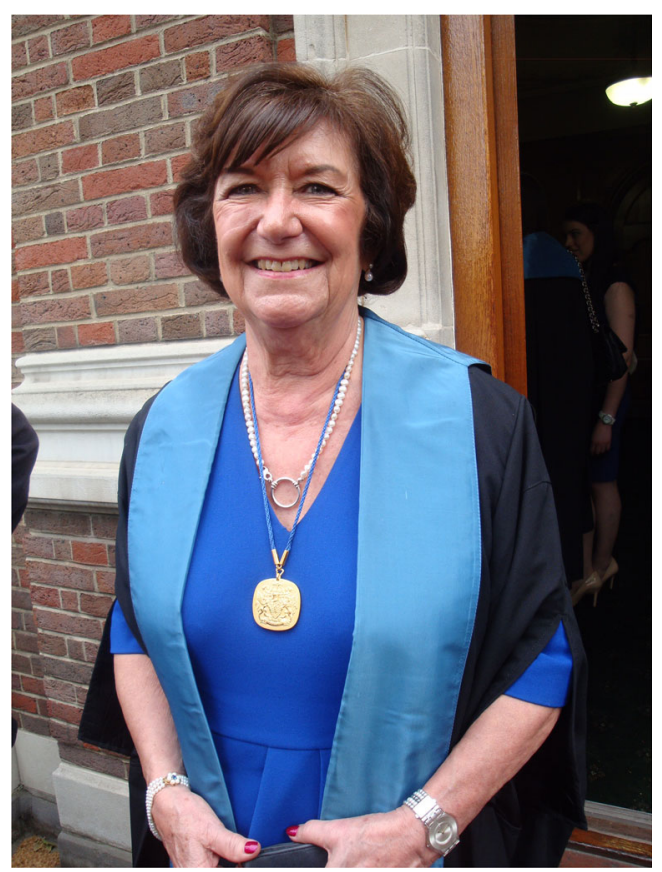

Professor Judith Elizabeth Adams, 'Judy' to her friends, an eminent skeletal radiologist, passed away after a short illness

K. A. Ward

kw@mrc.soton.ac.uk

1 MRC Lifecourse Epidemiology, Southampton General Hospital, University of Southampton, Southampton, UK

2 Department of Paediatric Endocrinology, Royal Manchester Children's Hospital, Manchester University NHS Foundation Trust, Manchester, UK on 30 September 2017. Judy was born on 16 May 1945 in Liverpool and grew up in Northern Rhodesia (now Zambia). She trained at University College Hospital, London, UK and her radiology career began in 1972. Her mentors included Sir Godfrey Hounsfield, the inventor of X-ray computed tomography, and Sir Charles Dent, a pioneer of work on metabolic bone disease in the UK. She joined The University of Manchester in 1976 and became a Professor of Radiology and Head of Clinical Radiology in 1993. She served as Dean, member of council and Vice-President of the Royal College of Radiologists. Judy was a member of many societies, including the American Society for Bone and Mineral Research, the European Calcified Tissue Society, the National Osteoporosis Society and the Bone Research Society; also the International Skeletal Society and the European Society for Skeletal Radiologists. She travelled the world attending the International Bone Densitometry Workshop and hosted the 1987 workshop in the UK.

Her clinical and research expertise lay particularly in the field of bone densitometry, quantitative computed tomography and vertebral fracture recognition. She contributed greatly to the development and application of bone densitometry in children and adults. She led and co-authored several national and international guidance documents for clinical application of bone densitometry in children and adults. In addition to her clinical expertise she carried out extensive research in the field of osteoporosis and bone densitometry throughout her career. She was awarded over $£ 5.5$ million by research councils, charity and industry, with $£ 750,000$ still in active research. This research resulted in over 200 peer-reviewed publications, 24 invited reviews and 34 book chapters, the last proof-read only 3 weeks before her death.

Her most notable contribution was her role in the collection of one of the first and largest UK reference datasets in children, which has transformed paediatric practice in the UK. 
She championed the clinical application of quantitative computed tomography in adults and also for research from the early days of its use, and for a long time her institution was the only UK centre that used the method. As part of this she collaborated closely with Prof. Harry Genant at UCSF. Judy worked tirelessly to emphasise the importance of identifying the presence of osteoporotic vertebral fractures. She subsequently worked on creating active appearance models for the semi-automated assessment of vertebral fractures from DXA and from clinical CT scans. She championed the Vertebral Fracture initiative of the International Osteoporosis Foundation. Through her role in the European Society for Skeletal Radiology, Judy provided a bridge between the radiology and bone fields.

Besides focusing on osteoporosis in adults and children of today, Judy also used her expertise to elucidate skeletal pathologies in ancient Egyptian mummies, both human and animal. This included making a diagnosis of osteogenesis imperfecta type V 3000 years after the event! She always loved new challenges in the application of imaging.

The Bone Research Society honoured Judy by inviting her to co-present the annual BRS Dent Lecture in 2015 with Professor Ignac Fogelman, recognising her contribution to developments in clinical imaging. In 2016, she was awarded the Linda Edwards Award of the National Osteoporosis
Society in recognition of her outstanding contribution to the field of osteoporosis. In radiology she was most recently awarded the Gold Medal of the Royal College of Radiologists (2016), following her Gold Medal from the International Skeletal Society (2007).

Judy was a tireless supporter of the National Osteoporosis Society, bringing her expertise as a radiologist to the charity. She served as a trustee, as a member of the medical board and the conference planning committee, and in the society's bone densitometry training scheme, along with other advisory roles.

Judy was a warm, thoughtful and loyal friend. She was a great mentor to both of us, and many other clinicians and scientists are indebted to her mentorship and tutelage. Her collaborations spanned the globe. She will be remembered by all for her elegance, her smile and her laugh, her bright clothes and her endless energy and enthusiasm. Judy was wonderful company both professionally and personally. Outside of work, she loved culture, from Manchester United through to opera, flowers, gardening and travel. Sadly Judy's husband of 45 years, Professor Peter Adams, an Emeritus Professor of Medicine at the University of Manchester, passed away a week later. They are survived by their two sons, Charles and James, and their three grandchildren on whom they doted, also by Judy's sister Jane and family. 